\title{
Astronyms in ancient Belarusian and Chinese texts
}

\author{
Alena Rudenka, Anastasia Putilina \\ Belarusian State University, Belarus
}

\begin{abstract}
The paper deals with one of the manuscripts of the National Library of Belarus - \# 091 / 276K Vilno Collection. Particular attention is given to unpublished texts of the Collection (pages 60-89). There are many names of stars and constellations translated from different languages and connected with different myths. The names of constellations in the manuscript are compared with similar names in the Chinese I Ching ("Classic of Changes") and the Historic Records by Sima Qian; some similarities in the principles of constellations' naming and the organization of astronymic systems are identified.
\end{abstract}

Keywords: manuscript, names of stars and constellations, Vilno Collection, I Ching, Historic Records.

The aim of this paper is to show general principles for the nomination of constellations. A study on a similar topic was presented at ICOS 2014 in Glasgow on material consisting of Slavic and German dialect astronyms (Ivashina and Rudenka 2014). The material of this article comprises ancient Chinese astronyms from the Book of Changes and the Records of the Grand Historian by Sima Qian, as well as astronyms from the Old Belarusian manuscript of the 16th century - the Vilno Collection.

The Vilno Collection is manuscript \# 091 / 276K from the National Library of Belarus. The I Ching ([î tcín]), also known as the Classic of Changes or Book of Changes, is an ancient Chinese divination text and the oldest of the Chinese classics. Possessing a history of more than two and a half millennia of commentary and interpretation, the I Ching is an influential text read throughout the world, providing inspiration to the worlds of religion, psychoanalysis, business, literature, and art. Originally a divination manual in the Western Zhou period (1000-750 BC), over the course of the Warring States period and early imperial period (500-200 BC) it was transformed into a cosmological text with a series of philosophical commentaries. The Records of the Grand Historian, now usually known as the Shiji, the Historic Records, is a monumental history of ancient China and the world finished around 94 BC by the Han dynasty official Sima Qian after having been started by his father, Sima Tan, Grand Astrologer to the imperial court. The work covers the world as it was then known to the Chinese and a 2500year period from the age of the legendary Yellow Emperor to the reign of Emperor $\mathrm{Wu}$ of Han in the author's own time. The Records has been called a foundational text in Chinese civilization. 
Among astronyms, there are old and new, scientific and folk names. Most of the old scientific names were formed on the basis of folk ones; certainly, these names are possible only for the visible objects of the sky. Precisely such astronyms will be discussed later.

There is a universal feature in all astronymic systems that does not depend on a specific language. It is the principal difference between the nomination of stars and planets and the nomination of constellations. The aforementioned and others are objects of the visible sky, but stars, united in constellations, have nothing in common. A man who looks at the sky groups stars in constellations. It means that constellations, unlike objectively visible stars and planets, are a figment of imagination. The same constellation correlates with different images: people, animals, objects, etc.

For example, in Belarusian dialects the Big Dipper is called Вллікал Мядзведзіиа (Bol'shaja Medvedica) 'a big bear'; Світальна, Cmaжap'e (Svitalna, Stazharje) 'light'; Anалонічак, Коўшык (Apalonichak, Kowshyk) 'a dipper'; Воз, Карэта, Калясніца, Павозачка, Брьчка (Voz, Kareta, Kalyasnitsa, Pavozachka, Brychka) 'wagon, cart'; Конь (Kon') 'horse'; $\Lambda$ ocb (Los') 'a moose'. Germanic names of stars and constellations are also plentiful: the Great Bear in English is called Ursa Major (in the German language there is the same name from Latin), the Great Bear, the Charles' Wain; asterysm the Big Dipper, the (Star) Plough, the Saptarishi (< seven rishis). Germ. der Große Bär is also called der Große Wagen, Wotanswagen, Irmineswagen, Karlswagen, Theiws Wagen, Himmelswagen, Wagen am Himmel, Eliaswagen, Peterswagen, Mariaswagen, Davidswagen, Wagen des Dietrich von Bern.

The image of an animal poorly correlates with the shape of a constellation. Nevertheless, the embodiment of an animal in a constellation was well conceptualized in Antiquity. The reason is that names of constellations reflected the ancient worldview and the very process of perception of the world by the ancients.

In modern China the European system of major stars and constellations, which goes back to the ancient tradition, is known (in this case, semantic calques are used). There is also the Chinese, more ancient system - to be more precise, several different systems. The ancient Chinese view of the starry sky is fixed in two manuscripts: the Book of Changes and the Records of the Grand Historian by Sima Qian.

According to the ancient Chinese astronymic system, the sky is divided into five parts, called 宫 [gun] 'palace, apartments'. These parts are compass oriented: 东 宫 [Dun-gun] - Eastern Palace, 西宫 [Si-gun] - Western Palace, 南宫 [Nan-gun] Southern Palace, 北宫 [Bay-gun] - North Palace. There also existed the Central Palace, which was associated with the emperor and his retinue. Each of the directions includes a large constellation, the name of which is associated with one of the mythical animals: 苍龙 [Tsan-lun]-Azure Dragon, 白虎 [Bai-hu] - White Tiger, 朱雀 / 朱鸟 [Zhu-tsue] - Red Bird, 玄武 [Suan-u] - Black Turtle. Here is the ratio of palaces and constellations:

- 东宫 [Dun-gun] - Eastern Palace / 苍龙 [Tsan-lun] - Azure Dragon;

- 西宫 [Si-gun] - Western Palace / 白虎 [Bai-hu] - White Tiger;

- 南宫 [Nan-gun]-Southern Palace / 朱雀 / 朱鸟 [Zhu-tsue]-Red Bird; 
• 北宫 [Bay-gun] - North Palace / 玄武 [Suan-u] - Black Turtle.

In turn, these constellations are divided into twenty-eight "lunar houses" - 二十 八宿 [èr shí bā xiù]. Twenty-eight constellations of the Chinese sky are important for astrological predictions and navigation.

The constellation Azure Dragon 苍龙 (eastern part of the sky) includes seven constellations: 氏宿-Basis, 房 宿-House; 角 宿-Horn, 立宿 - Neck, 心 宿 - Heart, 尾宿 - Tail, 箕 宿 - Basket. The Red Bird 朱雀 (south) includes 鬼宿 Daemon, 柳 宿 - Willow, 星宿 - Seven Stars, 翼 宿 - Wing, 井 宿 - Well, 张 宿 - Bow, and 输宿 - Cart. In the western part of the sky, White Tiger 白虎 consists of 奎宿-Scepter, 娄宿-Shackles, 参宿-Merit, 胃宿 - Stomach, 昴宿 - Hair, 觜宿 - Neb, and 毕宿 - Pitchfork. The northern part of the sky corresponds to the constellation Black Tortoise 玄武 and includes 女宿 - Virgo, 虚宿 - Emptiness, 危 宿 - Roof, 室宿 - Chamber, 壁 宿 - Wall, 北斗星 - Big Dipper, and 牛宿 - Bull.

The analysis of the Chinese names of constellations showed that the following principles of naming were used:

1. The metonymic principle: A is a part of a larger constellation B, for example, constellations Horn, Neck, Heart, Tail in the eastern part of the sky - Azure Dragon;

2. The sky is the "upper land" (the separation of the celestial sphere into "palaces", the constellation House in the eastern part of the sky, etc.);

3. The metaphorical principle: the similarity of the constellation's shape (form) to the object or phenomenon of reality (the Dipper in the constellation of the Black Turtle, etc.).

4. The "Mythic Model Principle", according to George Lakoff: "If there is a basic cultural myth in which B is A, then it is natural for B to be in the same category as A" (Lakoff 1986: 2-3) (= in our case it means to have the same name - A.R.). For example, the origin of the name of the constellation Cart in the southern part of the sky is associated with the myth of the goddess Shihe, who took out one of the ten suns on the cart each day.

The constellation Virgin has other Chinese names: Uniuj, or Siuniuj - the Maid, Zhiniuj - the Weaver-she. According to an ancient Chinese legend, Weaver was married to Bootes (Herdsman) in the same constellation of the Red Bird, and she stopped weaving. As punishment, the Lord of Heaven divided them by the Milky Way, and now they meet once a year on the seventh day of the seventh moon. By the way, for the Milky Way, the ancient Chinese had three names: 银河 [yinhe] 'silver river', 星河 [xinghe] 'star river' and 天河 [tianhe] 'heavenly river'.

5. Nomination with names of instruments (not always similar in shape) (the Pitchfork, the Basket);

6. The quantitative principle (for example, the Seven-Stars).

These principles are arranged in descending order: from the most frequent to less frequent ones. About half of the selected constellation names are characterized by multiple motivation, which means that naming principle can not be defined precisely. For example, the above-mentioned constellation the Cart, whose name is connected 
with the myth, looks a bit like a cart; so, the name may be based on the metaphorical principle of similarity in shape.

These ideas and principles are to be compared with Old Belorussian and in general Indo-European names of constellations. The second part of this research is devoted to the Old Belarusian manuscript the Vilno Collection. The Vilno Collection is a partially published manuscript of the 16th century from the Belarusian National Library. In this paper particular attention is given to unpublished texts of the Collection (pages 60-89), which has astrological content and includes several small articles. These texts were translated from a Hebrew manuscript and consist of excerpts from an ancient astrological treatise. Thus, there are many names of stars and constellations translated from different languages and connected with different myths - the text can be classified as hybrid.

In the Vilno Collection there are the names of all astrological signs and zodiacal constellations. The manuscript is very beautiful: on the margins of the book there are drawings of all the signs of the zodiac. The very word Zodia, denoting the zodiacal constellation, is of Greek origin and came to Old Belorussian through Latin. In Greek

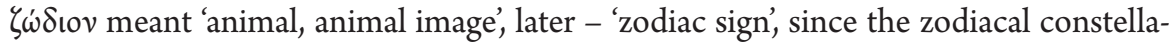
tions were represented by ancient Greeks as images of various animals and had corresponding names. The Ancient Greek names of zodiacal constellations go back to the astronyms of Ancient Mesopotamia. The ancient Greeks made calques of the Sumerian and Akkadian names and adapted them to their mythology, choosing the corresponding myths about each constellation (Куртик 2002: 81-82). This means that the Greek and Latin names of the zodiacal constellations are calques of earlier astronyms with secondary motivation according to the mythic model principle.

In turn, almost all the Slavic names of zodiacal constellations mentioned in the Old Belarusian manuscript are calques of Latin or Greek names. They do not differ from modern ones: водолец̆ (vodolej 'the Water-bearer' is a calque of Lat. aquarius), козеирогъ (kozeirog 'the Capricorn' - Lat. caprecornus), рыбы (ryby 'the Fish' - Lat. pisces), cmpeseus (strelec 'the Sagittarius' - Lat. sagittarius), wвенъ (oven 'the Ram' - Lat. aries), , левz (lev 'the Lion' - Lat. leo), pak (rak 'the Cancer'- Lat. cancer). Latin names, written in Latin and Cyrillic, are used in the manuscript in parallel with Slavic ones: Lat. aquarius - оуквариw (p. 67); pыбы [ryby] 'the Fish' - Lat. piscis - nuстес (p. 68); meseu [telets] 'the Bull' - Lat. taurus - maоypw (p. 68); дева [deva] 'the Maiden' - Lat. virgo - вирьго (p. 70); овен [oven] 'the Ram' - Lat. aries - ариш (р. 68); близнецы [bliznetsy] 'the Twins' - Lat. gemini - емень (p. 70); козерог [kozerog] 'the Capricorn' - caprecornus - капрекорьноу (р. 67).

In one of the articles a list of twelve astrological signs is given, in which the Slavic and Greek names are duplicated in the original and transcribed in Cyrillic letters:

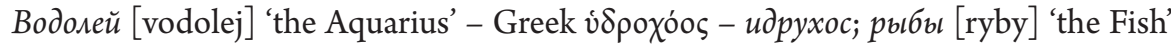

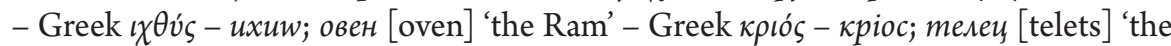

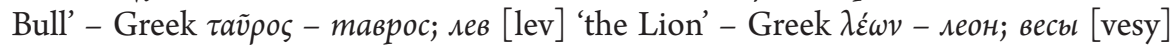

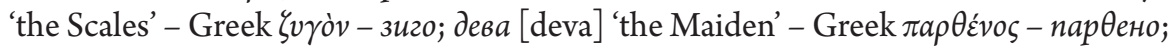


близнецы [bliznetsy] 'the Twins' - Greek $\delta \delta \delta \dot{\mu \alpha ~-~ д і д и м о ; ~ к о з е р о г ~[k o z e r o g] ~ ' t h e ~}$

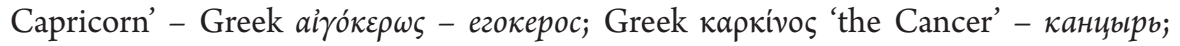

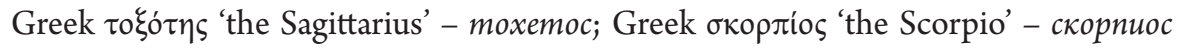
(Зомотарь 2016: 135-137).

Thus, in the Vilno Collection, as in a later manuscript than the Book of Changes or the Historic Records by Sima Qian, there are only ancient Latin and Greek astronyms. These names are written in the original (in Latin or Greek), in Cyrillic letters or as Slavic calques.

Dialectal Indo-European names of stars and constellations provide more opportunities for research into naming constellations than their literary names, which go back to ancient Latin and Greek names. Dialectal data show that the Indo-European system of the starry sky is holistic and similar for speakers of different Indo-European languages. The reasons for this similarity are the general laws of conceiving and comprehending the starry sky, as well as the early (common Indo-European) origin of astronyms, which were used primarily for orientation. The knowledge about stars (planets) and constellations was transmitted from generation to generation and from tribe to tribe as a part of this experience.

Indo-European, primarily Slavonic and Germanic, dialectal astronyms were presented at ICOS 2014 in Glasgow. The following naming principles were found:

1. Names may go back to cosmogonic myths, based on the so-called "Mythic Model Principle". For example, Rus. Volosozhary 'the Pleiades' is associated with the name of the god Veles, an important attribute of which is volosy 'hair', or wool. It is interesting that the holidays dedicated to Veles are in spring, when the Pleiades rise.

2. The similarity of constellations' shape to the object or phenomenon of reality (Rus. ковщu, Bel. апалонічак, коўшык, кораи, etc. with the meaning 'the Dipper'). This semantic model is represented in all Indo-European languages, as well as in many others: in the Finno-Ugric, Turkic languages; we have also seen a similar Chinese astronym 北斗星 'Dipper').

3. The quantitative principle (Germ. Drei Mäher 'three mowers', Drei Könige 'three kings', Drei Marien 'three Marys', Drei Stäbe 'three sticks', Drai Holzhacker 'three lumberjacks', Polish Trojki 'three', Trzy Siostry 'three sisters', Trzy Króle 'three kings', etc. names of the constellation Orion, in which three stars are clearly distinguished).

Similar to Orion associated with number three, the Pleiades is associated with seven, cf. Germ. Siebengestirn 'seven stars', Sieben Schwestern ' seven sisters', Engl. the Seven Sisters, Old Polish Siedem Gwiazd, Slovenian Sedem Zvezd 'seven stars', etc. Three and seven are magic numbers for all Indo-Europeans, so seven was not only seen in the Pleiades - see, for example, Engl. Saptarishi (< seven rishis 'seven wise men'), which is the name of the Big Dipper and goes back to Indian cosmology.

4. Position in the sky (Rus. kor [kol] 'pole' and Germ. Fixstern 'fixed pole' emphasize the most important feature of the Polar star - its immobility). The idea of a stake or pole is also known for Turkic and Finno-Ugric languages.

5. The names reflect economic relations; for example, the idea of celestial 
mowing and mowers is connected with Orion (Bel. dial. Kacubı [Kascy] 'mowers', etc.) (Ivashina and Rudenka 2014; Ивашина 2010: 274-275).

As we can see, the principles of astronymic attribution are similar in IndoEuropean and Chinese languages, despite the fact that the astronymic systems themselves are different.

A comparison of astronyms in different languages allows us to determine the universal features of the organization of astronymic systems:

- the idea of heaven as the "upper land";

- connection with the calendar, change of seasons, and agricultural work;

- the division of the visible starry sky into segments in accordance with the calendar and/or compass;

- ecliptic - imaginary line of movement of the Sun and visible planets;

- zodiac or its analogue - the visible part of the starry sky associated with the ecliptic;

- the zodiacal constellations are represented as "houses" of the Sun and moving planets;

- highlighting significant stars and constellations on the visible part of the starry sky for navigation and astrological purposes (zodiacal belt);

- connection of the key zodiacal constellations with the names of culturally relevant animals.

\section{Conclusion}

A comparison of manuscripts and dialects of different languages and different cultural traditions made it possible to determine not only the universal features of the organization of astronomical systems, but also the basic principles of naming constellations: the metonymic principle, the metaphorical principle, "the Mythic Model Principle", the quantitative principle, and the principle of reflecting economic relations.

\section{References}

Ivashina, N. and A. Rudenka. Names of stars and constellations in the Slavic and Germanic languages. In Names and Their Environment. Proceedings of the 25th International Congress of Onomastic Sciences. Glasgow, 25-29 August 2014, Vol. 5. Literary Onomastics. Other Names. Commercial Names, Carole Hough and Daria Izdebska (eds.), 104-113. http://www. icos2014.com/wp-content/uploads/icos2014_vol_5.pdf (accessed 08.08.2016).

Lakoff, G. 1986. Classifiers as a reflection of mind: a cognitive model approach to prototype theory. In Noun Classes and Categorisation. Proceedings of a symposium on categorization and noun classification, Eugene, Oregon, October 1983, Colette G. Craig (ed.), 2-22. Berkeley: University of California at Berkeley.

Голыгина, К. 2003. Звездное небо и Книга перемен. Москва: РАН, Институт востоковедения. [Golygina, K. 2003. Zvezdnoe nebo i Kniga peremen (The starry sky and the Book of Changes). Moscow: RAN, Institut vostokovedenija.]

Золотарь, М. 2016. Номинация созвездий знаков зодиака в старобелорусских текстах (на материале рукописи № 091\276К). Сборник работ 73-й научной конференции студентов 
и аспирантов БГУ, 16-25 мая 2016 г, 135-137. Минск: в 3 ч. Ч. 3. Минск: ИзА. центр БГУ. [Zolotar', M. 2016. Nominacija sozvezdij znakov zodiaka v starobelorusskih tekstah (na materiale rukopisi № 091\276K). Sbornik rabot 73-j nauchnoj konferencii studentov i aspirantov BGU, 16-25 maja $2016 \mathrm{~g}$. (Nomination of the zodiacal constellations in Old Belarusian texts (manuscript No. 091/276K). In Collection of works of the 73 rd scientific conference of students and post-graduate students of BSU, May 16-25, 2016), 135-137. Minsk: 3 v. V. 3. Minsk: BGU.]

Ивашина, Н. 2010. История становления славянской астронимической картины мира. Культурные концепты: сопоставительный анализ, 274-289. Ижевск: ИзА-во "УАмуртский университет". [Ivashina, N. 2010. Istorija stanovlenija slavjanskoj astronimicheskoj kartiny mira. Kul'turnye koncepty: sopostavitel'nyj analiz (The history of the Slavonic astronymical worldview. In Cultural concepts: comparative analysis), 274-289. Izhevsk: Udmurtskij universitet.]

Куртик, Г. 2002. О происхожАении названий греческих зодиакальных созвездий. Вопросы истории естествознания и техники 23 (1): 76-106. [Kurtik, G. 2002. O proishozhdenii nazvanij grecheskih zodiakal'nyh sozvezdij. Voprosy istorii estestvoznanija i tehniki (On the origin of the names of the Greek zodiacal constellations. Problems of the history of science and technology) 23 (1): 76-106.]

Рут, М. 1972. К вопросу о принципах номинации созвездий. Вопросы топономастики 6: 85-95. [Rut, M. 1972. K voprosu o principah nominacii sozvezdij. Voprosy toponomastiki (On the principles of the constellations' naming. Problems of Toponomics) 6: 85-95.]

Сыма Цянь. 1986. Исторические записки: в 9 т. Т. 4. Москва: Наука. [Sima Qian. 1986. Istoricheskie zapiski (Historic Records): 9 v. V. 4. Moscow: Nauka.]

Щуцкий, Ю. 1993. Китайскал классическал "Книга перемен”. Москва: Наука. [Shhuckij, Ju. 1993. Kitajskaja klassicheskaja "Kniga peremen” (Chinese classical "Book of Changes"). Moscow: Nauka.] 